\title{
Straddling Borders in Postcolonial Discourse: Delocalisation (Displacement) and Reconstruction of Literary Theory in Africa
}

\author{
Charles Ngiewih Teke
}

\author{
Associate Professor, European Union Researcher \\ Department of English and American Studies \\ Ludwig-Maximilians University Munich \\ teke@anglistik.uni-muenchen.de, tekengiewih@yahoo.com
}

\section{Doi:10.5901/mjss.2013.v4n3p169}

\begin{abstract}
This essay uses Edward Said's generated travel theory and affiliated theorists to discuss the question of the points of origin and different travel trajectories of poststructuralism and feminism in African studies. It argues that poststructuralism hitherto largely considered incompatible with African aesthetics and postcolonial theorisations and formulations is incontestably rooted in Africa and has contributed greatly in breaking Western essentialist epistemological structures and enhancing a variety of African postcolonial concepts. The major travel itineraries of poststructuralism can be traced as such: In Africa it is inscribed in the politics of struggle and resistance to colonialism and imperialism, in Europe it assumes a philosophical emphasis based on disrupting and deconstructing Western logocentrism and phonocentrism, in America it takes the guise of theory and method in literary discourse. Third World diaspora in this location adopts it in formulating cultural, minority, new historicist and postcolonial discourses. Its re-entry into Africa through African and Third World diasporic formulations consolidates and amplifies its point of departure from this continent. The reception and contextualisation of Western powered feminist discourses by African feminists and female intellectuals demonstrates difference. The accommodation or incorporation of Western feminist poetics by the latter lends credence to spatial, historical, cultural transformations, resulting in alternative routes though with a certain degree of universal interconnectedness regarding the plight of women. Western feminism is not homogeneous, implying that its essentialist apprehension of Africa as homogeneous gives room for different cultural and historical contestations in a multi-cultured African landscape.
\end{abstract}

\section{Introduction}

The advocacy for a pure African aesthetics in reading and interpreting texts authored by Africans is becoming rather outmoded, because of an impossible essentialist or totalising attitude which cannot be exclusively exclusionary of external influences, particularly Western. There has been resistance to appropriating or relating African postcolonial studies with Western or EuroAmerican theoretical influences (Chinweizu et al. 1983, Ngugi 1986, Ojaide 1996, 2012). Even when concessions have been made in certain theoretical domains, African studies have been generally hostile to postmodernism, especially poststructuralism or Deconstruction.

The thrust of this essay is not the contentions or disputes with regard to whether Western theoretical criticism is appropriate or not in formulating and articulating different strands of postcolonial criticism, particularly African literary and critical studies. The argument is that Western criticism, specifically poststructuralism as an offshoot of postmodernism, informs postcolonial criticism through travelling and transformations given that the spatio-temporality of postcolonial discourse is multiple and utterly controversial and unsettling (Appiah 1991, Shohat 1992, McClintock 1992, Ahmad 1995, Ashcroft 2001, Zeleza 2006, Ngugi 2012).

This essay will trace poststructuralism's ancestry or roots in continental Africa and show its various trajectories and discourses in Europe, its onward movement to the US and the different strands of theoretical issues it generates, and its journey back to Africa and its affiliations with postcolonial studies. As a vanishing mediator poststructuralism enters Africa not really as much itself, but mostly through Cultural studies, minority studies and new historicist studies which are more commensurable discourses with which postcolonial criticism finds comfort. Otherwise said, poststructuralism is generative in the inquiries of cultural, minority and new historicist studies with which postcolonial criticism affiliates.

The argument on travel theory goes further in the direction of the reaction of African feminist intellectuals towards White feminist essentialising epistemology on the universal subjugation and marginalisation of the woman. Feminism is rooted in the West, but it is not at all a homogeneous or singular discourse. Supposing itself as the centrality of female struggle for emancipation, Western White feminists claim to speak for and unyoke the universal burden of the woman, 
avoiding the myriad contesting spaces that make up the entire landscape of what is "feminist". Feminism has had diverse, and at times conflicting and irreconcilable trajectories within the same West, and Africa. Black feminist criticism in this vein would consist of the different currents and positionalities of African American thinkers located in the US, black British theorists, and African/diasporic theorists located and/or shuttling between Africa and the West. The accommodation or incorporation of Western feminist poetics by the latter lends credence to spatial, historical, cultural transformations, resulting in alternative routes though with a certain degree of universal interconnectedness regarding the plight of women.

Challenging any form of historical, cultural and literary essentialism in postcolonial studies, travelling theory is used here as paradigmatic frame of analysis, which functions as an undoubted historical imperative however relative, and a literary and cultural necessity. The within and without of postcolonial criticism shows different locations/filiations, trajectories, affiliations and continued dialogues. This travel metaphor is characterised by a movement of multiple crisscrossing and militates for an enriching field of studies in contemporary global exigencies. Poststructuralist dismantling of Western logocentric epistemology, disruption of the hegemony of democratic and political correctness, fragmentation of the subject, distrust of agency, resistance to or annihilation of theory, has been considered very unproductive to the humanities which aspirations it dismisses. Curiously, these same features, multiple as they are, militate favourably, and have been used consciously or unconsciously to enrich the endogenous epistemology that characterises African thought and criticism. This permeability has been enhanced by offshoots of poststructuralism in the guise of cultural, minority and new historicist studies. In this sense, it can be argued that there is certain shared positionality between postcolonial criticism and certain strands of postmodernist discourse however mutually antagonistic or warring they may appear to be.

The participle "straddling" is a careful grammatical and semantic choice in postcolonial formulations and articulations; straddle with reference to across, spanning, overlap, denotes mobility, continuity and open-endedness, not straddled borders as permanence, fixity or immobility. Postcolonial theory is rooted in an era which saw the global influence of modernity and its literary offshoot modernism, and its transition to postmodernity/postmodernism in Western and Eurocentric historiography and epistemology. Africa inadvertently contributed to these Western currents. In this vein it is impossible to theorise postcolonialism without these external implications, particularly the case of Africa. In terms of travelling metaphor and straddling borders, postcolonialism, far from assimilating uncritically, has received modernist and postmodernist poetics symbolically or metaphorically and immensely transformed and/or translated these, swerving from them and taking different trajectories with innovating, refreshing and enriching formulations. This paper argues that this dialogic interaction neither places postcolonial criticism in the fallacious binary of "self" and "other", nor considers it a peripheral discourse because of its inscription of imperialist literary and theoretical culture; it is not theoretical assimilé; postcolonial criticism conversely emerges as an eclectic or ecumenist discourse that prominently occupies a prestigious synergistic space in the global cultural and literary landscape.

Similarly, the African feminist is neither radical nor confrontational against received Western imaging of herself. She adopts a reconstructive and corrective politics in her general position vis á vis theory from the West. She recognises productive difference within her own location but is contemptuous of the structural pattern of binary oppositions with which the West analyses these dichotomous categories about her.

\section{Theorising travelling metaphor}

The concepts of exile, mobility and migration are timeless human phenomenon. Slavery, colonialism and imperialism consisted in mobility and displacement in different geographical locations. Theorising travel in terms of concepts and theories is even more complex and intriguing because displacement is not always necessarily physical, geographical; it can be ideological, most precisely metaphorical. The concepts of time and space become more complex as space goes beyond fixed geographical boundaries while, temporality depends on myriad and irreconcilable positionalities. Edward Said is a founding exponent of postcolonial theory who brought the issue of travel theory to prominence. However, enough attention has not been paid to this strand of postcolonial criticism. There is no doubt that some scholars have grappled with Western theoretical and philosophical influences on postcolonial discourse (Appiah 1991, Lazarus 2002, Leonard 2005, Olaniyan 2007, Anyokwu 2012), but the intricacies of Said's theory with regard to the metamorphoses undergone by displaced or exiled/migrant concepts/theories have not been carefully and extensively explored. This explains why postcolonialism can easily be dismissive of poststructuralism as a non-useful critical trope. Can one, for example, contest the fact that Said's celebrated seminal work and key text to postcolonial criticism Orientalism (1978) owes much indebtedness to poststructuralism of the Foucaldian sort?, that it is the translation of Derrida's deconstructive, On Grammatology that energised Spivak's postcolonial articulations, that Bhabha acknowledges the immense impact of 
Lacan, Derrida and Foucault on his thought?, or that Robert Young's postcolonial critical strength is inextricably linked to his being an ardent poststructuralist in Britain? Can postcolonial African literary studies disentangle or extricate themselves from Said, Bhabha and Spivak? Is the proliferation of difference characteristic of postcolonial discourses not compatible with poststructuralist positions against essentialism? Understanding the complexity of travel metaphor will inspire productive rethinking of any such contestation.

In 'Travelling Theory' Said presents the movement of theory in specific stages:

First, there is a point of origin, or what seems like one, a set of initial circumstances in which the idea came to birth or entered discourse. Second, there is a distance traversed, a passage through the pressure of various contexts as the idea moves from an earlier point to another time and place where it will come into new prominence. Third, there is a set of conditions - call them conditions of acceptance or, as an inevitable part of acceptance, resistances - which then confronts the transplanted theory or idea, making possible its introduction or toleration, however alien it might appear to be. Fourth, the now full (or partly) accommodated (or incorporated) idea is to some extent transformed by its new uses, its new position in a new time and place. $(157-158)$

Edward Said acknowledges that the demonstration of these stages may be complex. He also points to the fact that the journey and circulation of theories or ideas could be characterised by acknowledged indebtedness or unconscious connections and appropriations. David Huddart (2008) has also argued that theories have origins (roots), routes, and destinations, and none of these are ever final. A supposed end point is usually a start point, impossibly disentangled from the previous point. Basing his argument on the notions of filiations and affiliation he traces travelling metaphor to rootedness, travel, routes, destinations and locations, asserting: "Theories themselves, we might argue, become exiled when they are appropriated and transformed in the work of later critics, or re-contextualised in radically dissimilar theoretical contexts" (33).

Richard Clarke and James Clifford have theorised further the complexity of travel in connection to Said. In 'Travelling Philosophy' (2006) Clarke's adoption of Saidian itinerary on the concept of travelling theory is contextualised in philosophy migration from the West to the Caribbean. His focal argument is whether or not there is any such phenomenon as travel of ideas and theories. Clarke poses a series of questions and consents to the reality that definitive answers are impossible:

\begin{abstract}
What exactly is this thing called a 'theory' which is alleged to travel in this way? Is it synonymous with an 'idea,' as Said seems to maintain? If so, what precisely is an idea? What, in Aristotle-speak, is its 'cause'? i). Is the source of our ideas internal to human beings? If so, are ideas universal, unrestricted to any particular group? Does the mind work in a common way for all humans? ii). Is the source of our ideas external? If so, are our ideas localised, peculiar to the particular community which we inhabit? Is the mind culturally specific, as it were? (2)
\end{abstract}

These dizzying questions, "metaphilosophical" as Clarke coins them, are stimulating because of the variety of unending answers which can be provided. The issue as to whether the sources of ideas are internal or external to human beings or whether ideas are localised, perhaps fixed, is what postcolonial theory has been wrestling with for long. In the context of Said, theories or ideas enter into discourse due to multiple circumstances, and travel metaphor situates the resistance, acceptance, modification/reconceptualisation, accommodation or otherwise in different localities and different time axes. Travel can also be construed in terms of transformations and metamorphoses which ideas or theories undergo within the same space or locality but in different time axes.

Decentring, displacements, revisions, challenges, heterodoxy, hetero/transculturality, and heterogeneity are surely the broad terms with which one would review Clifford's articulations of travel theory in Routes (1997). Clifford appropriates his semantic context of travel with translation:

\footnotetext{
My expansive use of "travel" goes a certain distance and falls apart into nonequivalents, overlapping experiences marked by different translation terms: "diaspora", "borderland", "immigration", "migrancy", "tourism", "pilgrimage", "exile". [...] given the historical contingency of translations, there is no single location from which a full comparative account could be produced. (11)
}

Translations in Clifford's travelling terms are characterised by slipperiness and relativity, depending on perceptions and associations.

In "Notes on Travel and Theory" (1998) he contends that theory hitherto had been the preserve of the West, but this epistemological centre has been encroached by the non-Western theorists, "working oppositionally, with and against (both inside and outside) dominant terms and experiences." He underscores his main contention thus: 
Theory is no longer naturally "at home" in the West--a powerful place of Knowledge, History, or Science, a place to collect, sift, translate, and generalize. Or, more cautiously, this privileged place is now increasingly contested, cut across, by other locations, claims, trajectories of knowledge articulating racial, gender, and cultural differences. But how is theory appropriated and resisted, located and displaced? How do theories travel among the unequal spaces of postcolonial confusion and contestation? What are their predicaments? How does theory travel and how do theorists travel? Complex, unresolved questions.

This excerpt on the itineraries of theories best captures the contentions of straddling borders articulated in this essay, involving the relativity of postcolonial space, temporality and historiography. In Routes (1997) he had earlier premised that "Home is not, in any event, a site of immobility" (85). Clifford also acknowledges the complexity of travel concept but its implications cannot be doubted in postcolonial theory.

Mieke Bal takes up the same issue in her conception of travel with regard to interdisciplinarity, arguing that "They [ideas or theories] travel -between disciplines, between individual scholars, between historical periods, and between geographically dispersed academic communities." (24). Bal's conviction attests to dismantling the demarcations and boundaries which the academia capitalises on in terms of distinctive grounds of disciplines. Put in a broader perspective this trans-disciplinary approach to studies in the humanities informs and enriches shared affiliations and negotiations between or among supposedly compartmentalised disciplines. Travel theory in this sense offers a convincing way to trace connections and negotiations in ideas or theories.

This essay posits that travel theory is not just migration and uncritical assimilation of theories or concepts in diverse locations; travel theory engenders a discourse of dismantling, eroding any monolithic centre in favour of what I would call trajectorial negotiations, straddling borders which resist hegemony or point to no recourse to exclusionary or binary consciousness. Can African postcolonial criticism therefore make claims of locating or centring itself only within the postcolony? Can it circumscribe itself from any other discourse? What are the implications of postcolonial scholars of the Diaspora? Can it indeed make claims on purity of discipline? No.

\section{Postcolonial Reconstruction of Poststructuralism (Deconstruction): Suspicious Anti-humanism to Humanism}

This section examines the metaphor of travelling theory in the context in which postcolonial discourse has received, consciously or unconsciously sieved, transformed and translated poststructuralism, producing an altogether nuanced discourse to fit and enrich postcolonial poetics. Postcolonial discourse conveniently translates deconstructionist thinking creatively and constructively. Poststructuralism is far from being an alien discourse that came into Africa and the Third World without these locations contributing to "a set of initial circumstances in which [poststructuralism] came to birth or entered discourse". It is also rooted in Africa as one of its several points of origin, justifying Said's careful and cautious first point above with regard to travel and trajectories. A careful and critical survey of the different stages and itineraries or trajectories of Said's Travelling Theory shows that postcolonial criticism's acknowledged or unacknowledged disruption and accommodation of poststructuralism is an instance of modified, positive and constructive positionalities. The question of connecting poststructuralism's origin with Africa shows the complexity of pinning down the start point or entry into discourse of any theory to a particular location.

Some critics have premised their arguments against any mutual bonds that could exist between poststructuralism and postcolonialism, stressing instead that even if both share common characteristics there is really no give and take relationship between them. Let us examine two cases.

Helen Tiffin (1993) asserts that

A number of strategies, such as the move away from realist representation, the refusal of closure, the exposure of the politics of metaphor, the interrogation of forms, the rehabilitation of allegory and the attack on binary structuration of concept and language, are characteristics of both the generally postcolonial and the European postmodern, but they are energised by different theoretical assumptions and by vastly different political motivations. (172)

Despite Tiffin's conjecture that both derive their energy from different assumptions and political motivations, showcasing different unrelated locations, cultures, historiographies and epistemologies, there is no denying that the contact between Africa and the West has immensely impacted postcolonial theory which in turn is transforming Western academia whether this is acknowledged or not.

Philip Leonard (2005: 1 - 2) grapples with a comparative analysis which centrality is not the inter-implication of poststructuralism and postcolonial criticism; both discourses have their distinctive character. Leonard notes: "Poststructuralism 'itself' and 'before' postcolonial theory, it would seem, has nothing to say about colonial power, 
postcoloniality, globalization, transnationality, anticolonial resistance, or minority discourses" (3) and contest any appropriations of poststructuralism to postcolonial political agenda (19). These are all issues which form the centrality of postcolonial discourse. The travel metaphor is neither implicitly nor explicitly argued. These arguments only fuel the debate generated in this paper, they consolidate its positionality on straddling borders between poststructuralism and postcolonialism.

\subsection{The origin of poststructuralism (Deconstruction)}

Poststructuralism or better still Deconstruction might have gained more academic than social and political grounds because of its agenda to question and dismiss any constructive linguistic, social, cultural or political ordering on human life or discourse. Many have resisted the poetics of Deconstruction without carefully and critically considering its plurality of discourses and its immense impact on generating pluralistic ways of seeing things that had previously been considered unquestionable orthodoxies. Its roots and routes, its metaphors of travel are so complex, but interesting in the contexts of this paper's presumption. Connecting Africa with its roots may sound even delicate and obviously daring. Having used it transformatively and constructively I recognised its potential in reorienting and modifying my own hitherto hegemonic and essentialising criticism on English Romantic literature and its continental affiliations with German transcendental idealism (Teke 2006, 2012).

Decentring grand narratives, advocating the dangling nature of Eurocentric and logocentric thought and being highly sceptical of language as expressive of constructive thought, Deconstruction was undoubtedly a binary opposition to the holistic concerns of modernism.

A note on the postmodern condition is necessary to situate the hermeneutics of scepticism which strongly views culture, language and thought, history, theory as having failed in human endeavour - inscribed in poststructuralist thinking of intellectuals such as Jacques Derrida, Paul de Man, Joseph Hillis Miller, Jonathan Culler and Catherine Belsey.

In its EuroAmerican context postmodernist poetics was to an extent tenable, especially as it questioned, challenged and dismantled/deconstructed logocentric essentialist and totalising hegemony of the West. The so called grand narratives (related to reason, temporality, politics, sociology, literature) were simply put to question and neutralised, Western epistemology lost most of its grip as the unique global centre of knowledge and knowing; binary oppositions were rendered reductionist and fallacious etc. The problem with Postmodernism especially in the guise of radical Poststructuralism/Deconstruction was its positionality against the subject, agency, theory, and culture, in fact, its antihumanist and nihilistic turn with regard to the intensification of the existentialist unease borne of modernism. I am fervently convinced that most exponents in this regard generated much debate for mere academic consumption and consolidation of tenures in the academia.

It is interesting to know that a point of poststructuralism's origin is Africa, constituting a thread which extended into Europe and generated new trajectories. The poststructuralist exponent with whom this origin is associated is Jacques Derrida who to most African postcolonial critics is an ardent Western founder of Deconstruction, highly incompatible with the postcolonialist agenda. Robert Young has brilliantly rooted poststructuralism in Africa, thanks to his long standing and mutually beneficial relationship with Derrida. In his seminal essay "Subjectivity and History: Derrida in Algeria" (2007) Young argues that Derrida's critique of Western philosophy is primarily from his non-Western origin and positionality.

Young states that

Those who reject contemporary postcolonial theory in the name of the "Third World" on the grounds of its being Western, however, are themselves in doing so negating the very input of the Third World, starting with Derrida, disavowing therefore the non-European work which their critique professes to advocate. (623)

This excerpt contributes in dismissing the myth of criticism as uniquely Western, and as we shall see, this position by extension also helps in deconstructing the fallacy of feminism as a theoretical prerogative of the West. To Young poststructuralism was produced by a single historical moment, the Algerian war of independence in which Derrida participated and understood the deeper undercurrents of imperialism. Young's premise of a single historical moment may be an overstatement if one considers nineteenth century roots of Deconstruction in Nietzsche. Africa is considered here as one of the points of Deconstruction's entry into discourse. Derrida and Cixous, for example, studied in colonial Algeria, assimilated French culture, lived and continued their theorisations in France, but were in essence neither Algerian nor French. Other names associated with the war and poststructuralism are Althusser, Lyotard, Cixous, Bourdieu, Memmi and Fanon. Young documents their Algerian connections, "being Algerian and not being Algerian", and the productive energy derived from this Third World location in the formulations of poststructuralist discourse $(623-625)$. 
To accentuate the historical implication of the Third World Young situates the context of "post" in yet another insightful way:

Poststructuralism ... was in fact produced by repression, for it developed in large part out of the experience of colonialism. The structure to which it is 'post' is the colonial apparatus, the imperial machine. Its deconstruction of the idea of totality was born out of the experience of, and forms of resistance to, the totalising regimes of the late colonial states, particularly French Algeria. (625)

A particular brand of poststructuralism can be discerned in Africa from this perspective. Colonial and imperial totalitarianism produced the structures on which colonised states operated. The resistance and deconstruction of such totalitarianism resulted in a post structure or so it seemed. Poststructuralism in this sense can be interpreted as postWestern-colonialism which orchestrated unending pluralistic structures in Africa. Postcolonial theoretical imprints were already rooted in Africa before poststructuralism travelled to and took its philosophical turn in Europe.

Poststructuralism in Europe, its trans-Atlantic adaptations in America, its peak, decline and generation of alternative discourses which implicate African criticism all testify to travel and what obtains when borders straddle. Deconstruction in Europe did not begin with the arrival of Derrida et al. It also had its European point of departure in the thinking of Nietzsche (Zima 2002). Derrida, Lacan and Kristeva are some of the hardcore deconstructionists. Michel Foucault, Roland Barthes and Pierre Macherey also constituted a brand of European poststructuralism. The theoretical and literary implementations of Deconstruction in America included names such as Paul de Man, Hillis Miller, Geoffrey Hartman and Harold Bloom. Third World intellectuals such as Edward Said, Gayatri Spivak and Homi Bhabha tapped from European poststructuralism, especially that which was rooted in Africa.

The major travel itineraries of poststructuralism can be traced as such: In Africa it is inscribed in the politics of struggle and resistance to colonialism and imperialism, in Europe it assumes a philosophical emphasis based on disrupting and deconstructing Western logocentrism and phonocentrism, in America it takes the guise of theory and method in literary discourse. Third World diaspora in this location adopts it in formulating cultural, minority, new historicist and postcolonial discourses. Its re-entry into Africa through Third World diasporic formulations consolidates and amplifies its point of departure from this continent.

\subsection{Postcolonial trajectory and nuanced itinerary}

We have established that the reception of Poststructuralism is complex, depending on its multiple travel itineraries. Deconstructionist articulations immensely helped, consciously or unconsciously, postcolonial formulations and articulations. Postcolonial theory celebrates difference, relative historiographies and alternative epistemologies; these cannot be disconnected from postmodernist articulations, but they are far from ascertaining Postmodernism.

African postcolonial theorisations prioritise issues of nation, state, identity, agency, representations and constructive difference. Given that poststructuralism theorises against all these issues, there are unavoidable questions to grapple with:

- How is poststructuralist conception of subjectivity, the deconstruction of the subject compatible with postcolonial preference for agency? How does postcolonial criticism translate the dismantling of the subject into its poetics?

- How is poststructuralism itself a repository of existing and philosophical construction,? A site of a myriad discourses with regard to linguistic and philosophical theorisations?

- How have Deconstructionist expressions like fragments, decentring, deferral, dispersion, dissemination, displacement, undecidability, semantic instability, irony, unresolved contradictions, impasse, ambivalence, dissolution, traces, bricolage, supplement, suture etc. been used in postcolonial discourse and conceptualisations?

- To what extent has Deconstruction's theorisation of the impasse between language and rational thought been beneficial to postcolonial critics and scholars? How have postcolonial scholars used Deconstruction in utter violation of Western precepts in deconstructionist poetics?

Answering these questions pose no real difficulties if one were to understand the intricacies of theoretical crosspollination, the new uses which one makes of a discourse in different locations and cultures. Many postcolonial critics have engaged with these questions knowingly or unknowingly, and the answers have often produced discourses in different directions other than poststructuralist lines. Postcolonial historiography is an unsettling area of discourse 
because of the multiplicity of contentions on its semantic fields. It is true, however, that postcolonialism and poststructuralism are incompatible in terms of context and historiography as broad categories. But it is uncontested that a link can be drawn between the two in the axes of travel, receptivity and alterations, which at times are very radical. I once suggested in my home university in Cameroon that we could profit immensely from poststructuralism if we examined it in our own terms. I introduced it in my course on Critical Theory, but was told by a superior colleague that it was absolutely useless in an African academy, having nothing to offer students who could be agents of change. On arguing that it could contribute to postcolonial studies I was told that these two were radically opposed, in fact, it was like going into a desert expecting to accomplish a hunting spree. I was later derogatorily branded "the Deconstructionist". I still stand my grounds today.

Said discusses in his third phase of travel theory that the entry of an alien discourse into a new location results in acceptance, toleration, transformation or resistance and confrontation. Unanimity is a word hardly used among theorists. The truth therefore is that any travelling idea or theory will always meet with both consciousnesses in whatever location of its entry. African scholarship offers salient examples of resistance, intolerance and contestations. We will take two examples.

In his discussion of poetic imagination in Black Africa Tanure Ojaide (1996) is very uncomfortable with Western derivatives in reading and interpreting African poetic texts: "...theories and art are cultural products...many of these foreign spawn theories have made African writing and writers look ludicrous at best and inferior at worst. Do these theories help the reader to understand African literature? An emphatic No" (ix). To Tanure it is disingenuous to use any Euro-American based theory to interpret or judge African poetry and by extension postcolonial literature; he insists on relying on the total experience of people to understand their literature. The expression "total experience" sounds disturbing and essentialist in a continent with multiple colonial and neo-colonial connections. Tanure's unease and resistance to Western theory is consistently advanced in "African Literary Aesthetics: Continuity and Change" (2012) in which he decries the overwhelming dominance of the West in the global scene and the perilous situation this has left Africa in (116). Considering Western theoretical discourses like structuralism, feminism and deconstruction as trendy and boxes into which African literature is squeezed, Tanure advocates unique qualities in African literature, resulting to the affirmation of Africanity (117).

Olaniyan presents a seeming dichotomy or polarity between postmodernism in which poststructuralism is inscribed, and postcolonialism which is yet to begin:

If postmodernity does not describe socio-historical conditions that obtain in Africa, then it is not logical for postmodernism, the discourses of self-constitution and self-understanding of postmodernity, to apply to the continent. By the same logic, postcolonialism references the discursive formations of contexts in which colonialism has ended. And that is not yet in Africa, as many scholars of Africa are wont to argue. (637)

This excerpt is not Olaniyan's conviction seen in his analysis and conclusion of his essay, but offers a challenging contested space of argument which is worth considering. Suffice to say here that Africa provides one of the roots of poststructuralism an offshoot of postmodernism, which describes socio-historical conditions of Africa.

\subsection{Transformations and new semantic contexts}

David Huddart (2008) hypothesises that "Postcolonial theory is the house style of an upwardly - mobile diasporic academic community, and is therefore far removed from the realities of the colonialism it purports to discuss" (41). Huddart is obviously concerned with the location of the critic and not the impact of his theorising. It becomes evident with such a position that postcolonial critics are merely academicians in the diaspora. Linking them with poststructuralism which is conceived as an entirely Western discourse would simply mean more substantiation to Huddart's premise.

With reference to the journey metaphor in Saidian terms, the third and fourth phases are vital here. This is a complex issue which goes beyond the question of the "colony writes back" and engages in a myriad of interconnectivities characterised by conceptual positionalities, dismissing primarily the imperial discourse of binary oppositions and any totalising epistemology.

Simon Gikandi's 'Poststructuralism and Postcolonial Discourse' shows the implications of the appropriation of poststructuralist discourse within the various discourses of postcolonialism, arguing that postcolonial discourse found its roots within European institutions and the matrix of European criticism after structuralism; "a postcolonial discourse is unthinkable without poststructuralist theory" in this direction (615). The thrust of his argument is the contribution of Sartre 
to postcolonial theory. What obtains in Gikandi's essay provides the uncontested context in which one can argue the validity of travelling theory and necessitates extensive citation:

\begin{abstract}
Locating postcolonial theory within this European genealogy, however, raises another set of questions or problems: why have theoretical questions that originally developed within French theory come to dominate debates about Anglophone postcolonial identities, cultures, and literatures? Is postcolonial discourse about how French theory plays out in the institutional practices of Anglophone intellectuals rather than a theoretical reflection on what Neil Larson calls "the realities of cultural decolonization or international division of labor" ... or is it a technology for understanding the postcolonial condition? A different gloss on the same problem is presented by Bhabha ... "Is the language of theory merely another power ploy of the culturally privileged Western elite to produce a discourse of the Other that reinforces its own power-knowledge equation?" (615).
\end{abstract}

These important questions should not be viewed in terms of trying to essentialise postcolonial criticism but to build a solid argument in the direction of how it skilfully and critically taps into poststructuralist theory to produce innovating and constructivist discourses that inscribe themselves in an equal space with so called Western theoretical tenets. It is to analyse the intrusion of French criticism into English intellectual space and celebrate postcolonial criticism's strength in producing a discourse which suits its spatio-temporal locations and also dismantles its derivative sources.

The main issue or contention is not the location of the postcolonial scholar or theorist, especially seen as having migrated and produced a discourse in the West dominated by Western theory. The interest lies in studying the subtle dialogic inbetweenness characteristic of the metaphor of travelling and how theoretical borders straddle. This explains why Gikandi contends that postcolonial discourse cannot be dislodged or better still dissociated from French poststructuralism as it shows the extent to which travelling is materialised in the imagination of the postcolonial critic. This essay takes the debate further, arguing that European poststructuralist metaphorical travel to the US grounded its connectedness to the Anglophone world, and this involved, as we have mentioned, new trajectories as the Yale school was more concerned with literary theorisation and practice, and the likes of Said and Bhabha continued the deconstructionist agenda on historical and political grounds.

One of the African scholars who has paid attention on the uneasy but fruitful relationship that can be established between poststructuralism and post-colonial critical formulations is Tejumola Olaniyan. In fact, he militates for the rewarding relationships which seemingly irreconcilable positions can establish rather than ascertaining a permanent impasse. Though his paper is neither implicitly nor explicitly concerned with travel theory it all the same throws light on the direction of this essay's contention that postcolonialism borrows from poststructuralism, seen in this case as travelling concept from the West. In "Postmodernity, Postcoloniality, and African Studies" (2007) Olaniyan cautiously avoids the self-deceptive and problematic term postcolonial and concentrates on the trajectory of African studies' accommodation of poststructuralism. He argues that while postmodernity and postcoloniality represent different temporalities they are mutually inclusive theoretically. He points out the three major issues with which African critics rest their case against postmodernism and its signifiers; its decentring of the subject, its exhorbitation of culture and its abstruse language (637 -629). This is a very ironical situation as this essay would have it, given that what readily comes to mind on mentioning postmodernism and poststructuralism is a unified and unidirectional discourse, the West being its centre. Conversely, the situation legitimatises displacement and travel, resulting resistance or modified construing. One only needs to be reminded that Derridian discourse is not Foucauldian, that de Manian theoretical deconstruction is not Bloomian and that Bhabha specifies whatever poststructuralists turn and exponent he engages with.

Olaniyan assumes the position of transforming or translating poststructuralism within the African context by pointing out the productive and constructive nature of the very issues which African critics have raised against poststructuralism. Postmodernism, he contends, is an expression of the epistemological humility of the West (641) and by extension a welcome discourse in Africa's anti-colonial and anti-imperial rhetoric. The deconstruction of the subject is liberating for African studies which has given way to understanding African subjectivities and identities $(639,642)$. Dismantling Western epistemological hegemony has given room to relativism. African studies can engage in multiple histories and multiple locations of knowledge within and without itself (639). In fact, Olaniyan holds that postmodernism has inspired a variety of scholarship in Africa. He concludes that "...no discourse is homogeneous in formation" (644) and that whatever their ideological differences, postcolonialism has borrowed from postmodernism. What is important is what African studies stand to benefit from any discourse no matter its origin. What one discerns here is postcolonialism's humanisation of postmodernism in African contexts.

The circulation of theories and concepts have been received, cast off, embraced, amplified, re-construed, transformed and translated in different time axes, different locations and different contexts of knowledge and knowing. A very careful study of African scholars' and writers' articulations would demonstrate that they have knowingly or 
unknowingly criss-crossed aesthetic and theoretical borders with the West, have engaged with postmodernism and poststructuralist poetics. Authorities such as Achebe, Ngugi wa Thiong'o, Soyinka, Armah, Gikandi, Mama, Nnaemeka, Mbembe, Olaniyan, Nyamnjoh, Bate Besong and Nkengasong provide critical examples to the profit of studies in their African locations, not to the celebration of poststructuralism in its typical Western dressing.

\title{
Western Feminism and the Postcolonial African Female Perspectives: The Aesthetics of Lying Disseminated and Deconstructed
}

This section continues the premise of the metaphor of travel theory in terms of Western feminist claims of being the centre of discourse with reference to other cultural locations and epistemologies. It therefore wrestles with the entry into Africa and African Diaspora of Western postulations to its essence, and how it has been received, challenged and reconstructed by the African feminist. Colonialism and patriarchy have been considered by the intellectual Western female scholar/writer and a breed of African female intellectual surrogates as exclusionary perpetrators of the same ideology of dominance and quiescence of female voice and power. Colonial and imperial ideology in its usual totalising agenda produced and represented Africa's self image and knowledge (Ali Marzui 1986, Ngugi 1993, 2012, Nyamnjoh, 2012). The West made Africa or Africanised Africa to use Marzui's terms. In other words the African could define or represent his/her identity only from what was inscribed in Western invention of the continent. This holds true for gender images which have been perpetuated and assimilated uncritically as the true image of the African social system to the point that some female scholars resent and discard the cultural contexts in which they have to negotiate with imported misleading academic and intellectual discourses. The misrepresentations and distortions, prejudicial constructs and fallacious myths seem to be the truth for such thinkers. It is in such a context that we propose Nietzsche's conception of truth to situate the fallacy of a universal voice for the woman which emanates undoubtedly from the North, and to discuss the different trajectories of feminism as semantically and culturally unstable:

\begin{abstract}
What then is truth? A mobile army of metaphors, metonymies, and; anthropomorphisims: in short a sum of human relations which have been poetically and rhetorically intensified, transferred, and embellished, and which, after long usage, seem to people to be fixed, canonical, and binding; Truths are illusions which we have forgotten that they are illusions - they are metaphors which have become worn out by frequent use and have lost all sensuous force, coins which have lost their embossing and are now considered as metals and no longer coins. (Friedrich Nietzsche: "On Truth and Lying in a Non-Moral Sense")
\end{abstract}

This excerpt points to a number of issues; firstly, canonised feminist epistemology from the West, and secondly, colonial and imperial epistemology of gender stereotypes, paving the way for what would be considered an Africanist angle and route in feminist discourse. However valuable, informing and insightful Western feminism may be in its multiple discourses like radical feminism, psychoanalytic feminism, Marxist feminism, poststructuralist feminism, eco-feminism and lesbian feminism, there remains a huge anxiety and unease grouping all these into a holistic movement. This undoubted heterogeneous circumstance is pointer to an untold self-undoing of Western rhetoric which has always remained ambivalent, contradictory and radically unsettling.

Western feminists disturbingly pass for the location of origin and centre of African female theoretical formulations, considering Africa only as a repository of African realities or uncivilised, gruesome and barbaric space of experience. It is not shocking to say that the pedagogy and curriculum of African female self-knowledge has for long been designed and canonised by her very "concerned" Western sister who at the same time passes for her mouthpiece and spokesperson. The colonial and imperial content of this curriculum, characterised by falsehood and grossly erroneous representations, is disgusting to say the least. The question is whether there is a true universal feminist turn, a central reservoir from which sameness can be drawn, from which cultures genuinely intermix without the stigmas of race, class, location, historiography and sexual orientations.

Feminism in Western feminist epistemology is generally confrontational, anti-man and anti-religious; it excludes man and militates for a totalising female power structure. The colonial era deconstructed existing gender representations and imposed a cultural variation not very compatible with what characterised African lived experiences and thought. In fact, the African woman has to look up to her Western superior sisters who master their plight and can speak for them best. What are the implications of travel theory at this point of argument? How can this metaphor be analysed? What characterises the reception of this discourse of dominance, based on falsity and fallacious essentialism? What are the different poles and directions with which this essay is specifically concerned? 
Adrienne Rich and Gayatri Spivak have generated alternative epistemologies which move in line with the propositions of committed African female intellectuals and activists in face of the totalising dogmas from the North. Adrienne Rich has played a significant role in the recontextualisation of feminist criticism, challenging, deconstructing, disabling, and decentring White women's global dominance and erroneous hegemony of feminist discourse. "Notes Toward a Politics of Location" was presented in June 1984 in the Conference on Women, Feminist Identity and Society in the 80s, and published in Blood, Bread and Poetry (1994: 210 - 231). Questioning the supposedly unique and authentic voice of the white woman as feminist spokesperson she asserts that:

\begin{abstract}
Marginalized though we have been as women, as white and Western makers of theory, we also marginalize others because our lived experience is thoughtlessly white, because even our "women's cultures" are rooted in some Western tradition. Recognizing our location, having to name the ground we're coming from, the conditions we have taken for granted - there is a confusion between our claims to the white and Western eye and the woman-seeing eye, fear of losing the centrality of the one even as we claim the other. (219)
\end{abstract}

One does not need to belabour the one-sided and exclusory discourse that white feminism is imposing on the global feminist culture which is plural. It is in this seminal paper in which she revisits and revises some previous totalising views of the white woman and patriarchy or male evil as root to woman's marginalisation and victimisation. She had come "with notes, but without absolute conclusions" (211), demonstrating with shrewdness and subtlety an open ended mind that resists closure and finality. In this vein, she convincingly argues for a plurality of views regarding the lived cultural experiences of women from myriad world locations and intellectual positions. These different locations would enrich different alternative strands of representations. She contends that a white feminist consciousness can actively be built, but one that resists white circumscribing and not centred only on itself (219). She is very cautious of the slippery collective pronoun "We" which has passed for a non-contradictory voice of world womanhood in Western universalist representation. Reiterating the question "Who is we?" only fuels the debate on whether there are several "we" from multiple angles.

The female postcolonial authority Gayatri Spivak insists on being feminist but not in seeing the plight of the woman in terms of a totalising discourse of her suffering under oppressive male power as hardcore Western feminists would have it. In 'The Intervention Interview', The Post-colonial Critique, Spivak is unequivocal on her deconstructionist position with regard to the polemic of universalising women's problems. Finding feminism branded as a "single-issue movement somewhat terrifying" because of its totalising agenda, and "deeply concerned with a persistent critique of a totalization which can in fact in the long run lead to totalitarianism" (118), Spivak stresses a dismantling of such hegemony for a pluralistic option of different localities and realities without effacing her feminist identity. This position has even led some Westerners to style her anti-feminist. Her re-appropriation of the question is proof of a different trajectory and the extent to which travelling theory engages new itineraries.

Black feminism and precisely African feminism is certainly a pluralist discourse in the continent which takes a different trajectory from the hegemony of Western dominated positions against patriarchy in which the woman is unavoidably constituted.

As a student of Western literary studies, my meaning of patriarchy was derived from Western discourse, particularly articulations of feminist stances which have centred on the fallacy of women's universal oppression by men. From a transformational perspective I construe patriarchy not uniquely as a question of male hegemony and dominance over female but more precisely as constituting structures of power relations which include both males and females, at least in the African epistemology. There are powerful female hierarchies in certain African cultural communities, which would be neutralised in a universalist discourse. Little focus is paid by feminists to female dominance resulting from class, race, colour and sexual orientations. Unassimilated African female scholars will certainly take side with the contextual definition proposed here, not altogether refuting the possibility of a world sisterhood of shared assumptions.

This essay wrestles with the reception and digestion of Western feminism by three of Africa's prominent feminist scholars Oyewumi O., Obioma N. Nnaemeka and Amina Mama. Both Oyewumi and Nnaemeka address pertinent issues of how the Western academia claims to be the global spokesperson for the feminist movement, thereby erroneously bundling African women into the matrix of a single, evasive and grossly distorted homogenous set. They both strongly decry such a situation and express the same propositions of Spivak who is considered curiously in the West as antifeminist simply because she has not aligned herself to the over-intellectualising feminist built-up of the West and global sisterhood of the North.

Oyewumi in "Visualizing the Body: Western Theories and African Subjects" (2005) writes: 
From a cross-cultural perspective, the implications of Western bio-logic are far-reaching when one considers the fact that gender constructs in feminist theory originated in the West, where men and women are conceived oppositionally and projected as embodied, genetically driven social categories... On what basis are Western conceptual categories exportable or transferable to other cultures that have a different cultural logic? This question is raised because despite the wonderful insight about the social construction of gender, the way cross-cultural data have been used by many feminist writers undermines the notion that differing cultures may construct social categories differently. (11)

The words exportable or transferable signal change of setting into which discourse is displaced. The new space [Africa] is not void of its own dynamic identities. Oyewumi does not dismiss Western feminist theory, but appeals for a broader view on gender representation which would involve a variety of cultural logics. This would avoid, she conjectures, the undermining of other social and cultural constructs which are not Western.

Obioma Nnaemeka in "Nego Feminism: Theorizing, Practicing, and Pruning Africa's Way" (2004) embraces African culture and its dynamism, Africanises feminism with the advocacy of nego-feminism, not a narcissistic ego feminism, not confrontational or oppositional rhetoric against men as inscribed in typical Western theorisations. She explains:

First nego-feminism is the feminism of negotiation; second nego-feminism stands for "no ego" feminism. In the foundation of shared values in many African cultures are the principles of negotiation, give and take, compromise and balance. African feminism[s] (or feminism as I have seen it practiced in Africa) challenges through negotiations and compromise. It knows when, where, and how to detonate patriarchal land mines; it also knows when, where, and how to go around patriarchal land mines. (22)

This position carries with it an unchallengeable nuanced perspective, justifying the unfixed nature of feminist theory. Its entry into African discourse does not signal rejection, but a differing position, particularly as to what strategies needed to assure the woman's space. It reminds of Omolara Ogundipe-Leslie's -stiwanist (Social Transformation Including Women in Africa) discussion "Stiwanism: Feminism in an African Context," 2007: 545 - 547, 549. Similar concerns find expression in Sinmi Akin-Aina's "Beyond an Epistemology of Bread, Butter Culture and Power: Mapping the African Feminist Movement" (2011).

The most incisive reaction to Western feminist's erroneous positioning of itself as the universal voice of the woman is articulated in "Bringing African Women into the Classroom: Rethinking Pedagogy and Epistemology" (2007):

\begin{abstract}
We African women have witnessed repeatedly the activities of our overzealous foreign sisters, mostly feminists who appropriate our wars in the name of fighting the oppression of women in the so-called third world. We watch with chagrin and in painful sisterhood these avatars of the proverbial mourners who wail more than the owners of the corpse. In their enthusiasm, our sisters usurp our wars and fight them badly-very badly. The arrogance that declares African women "problems" objectifies us and undercuts the agency necessary for forging true global sisterhood. African women are not problems to be solved. Like women everywhere, African women have problems. More important, they have provided solutions to these problems. We are the only ones who can set our priorities and agenda. Anyone who wishes to participate in our struggle must do so in the context of our agenda. In the same way, African women who wish to contribute to global struggles (and many do) should do so with a deep respect for the paradigms and strategies that people of those areas have established. In our enthusiasm to liberate others, we must not be blind to our own enslavement. Activities of women globally should be mutually liberating. (573)
\end{abstract}

This excerpt communicates evidence that the African woman has been written and imaged by an external other who has created a myth about her contextual realities. This is very disturbing, even annoying. This Western narrating and theorising of the African woman has, on its reception, produced a counter discourse by the subject of the writing, the African woman in face and experience of her realities.

Nnaemeka carefully analyses the different ways the African feminist would handle delicate phenomena as clitoridectomy, polygyny and arranged marriages, all denounced and debunked by Western feminists who construe them as dehumanising and evil $(574-576)$. These are issues which are far from being concrete instances of untold abuse of the woman's body, the enslavement of the African woman and the uncivilized nature of the continent Nnaemeka strongly argues. The cultural contexts in which these practices are grounded are hardly understood by the Western theorist who is fixated with misconceptions and misrepresentations.

The contemporary African feminist and activist Amina Mama has lived, witnessed and experienced what it means to be black in feminist discourses in diverse world locations. From Nigeria to Britain (involvement with the Black Forum and Organisation for Women of Africa and Asian Decent), from Britain to South Africa (founder of African Gender Institute and editor of Feminist Africa) and from South Africa to America, and shuttling within and without these spaces, she has a 
deep understanding of black female subjectivities in face of White female theorisations. She is the very embodiment and metaphor of travel and has contributed immensely to ascertaining the place of the black woman in global feminist issues.

The deconstruction of the black subject constructed by white scientific psychology and the construction of postcolonial black subjectivities is Mama's central preoccupation in Beyond the Masks: Race, Gender and Subjectivity (1995). The construction of racialised identities, the imaging of the inferior nature of the black without any grounded knowledge of cultural difference is considered by Mama as a supremacist strategy in post-enlightenment assumptions, as "enslaving the soul of the other". The white powered Women's Liberation Movement, she argues, is not centre of world sisterhood as it misconstrues black identity, is racist and anti-sexist. The entity of feminism as a global discourse must constitute the differences of diverse local spaces, she asserts.

In her criticism we discern the dialogic relation of Western and African feminism as metaphors of travel in both Western and African directions:

\begin{abstract}
However, the historical record tells us that even white women have always looked to Africa for alternatives to their own subordination, since the days of the early anthropologists. Look how the English dispatched anthropologists like Sylvia Leith Ross and Judith Van Allen to try and make sense of the Women's War of the '20s! So we have always been part of the early conceptualisations of so-called 'Western feminism', even if not properly acknowledged as such. More importantly African women have always defined and carried out their own struggles. African feminism dates far back in our collective past-although much of the story has yet to be researched and told. (Interview with Elaine Salo, 2001)
\end{abstract}

She goes further to say that African feminists must define their terms in the context of their cultural and social realities, opposing the "northern-based white women's relative power to define" and claiming that the configuration of feminist thinking necessitates different discourses of female oppression with regard to class, race and culture. She consents to strategic and discerning alliances with men for their liberation and empowerment of women. Western feminism, Mama contends, has been influenced greatly by the nuanced discourses produced in Africa, Asia and Latin America. She acknowledges the fact that Western feminist thinkers have listened to African and other Third World female voices, and are re-considering the simplistic paradigms with which they viewed blacks.

The building of a feminist intellectual community in Africa is what Mama wrestles with in "What does it mean to do feminist research in African contexts" (2011). She points out the extremely heterogeneous nature of African feminism orchestrated by diverse colonial contexts, a multiplicity of civilizations and a vast array of anti-colonial and national movements. She advocates an activism which draws from "the repertoires of international feminism, which generally takes the pursuit and exchange of knowledge across contexts and borders seriously" (5) but focused on strategies which are based on the trajectory of African cultural, political and socio-economic realities.

\title{
A Note on African Male Authors
}

In terms of travel theory through creative writing, since I consider certain forms of writing as theory creating or enhancing, African male writing has contributed immensely to perpetuating the African woman in strong positions of importance and power symbolically and practically. African male writers have been very instrumental in writing and representing the female image in such ways as deconstruct the stereotypes which the colonialist/imperialist wanted ingrained in memory about the debased nature of the African woman. Nnaemeka and Ogundipe-Leslie would not have chosen the appropriate coinage nego-feminism and stiwanism respectively on accidental grounds. Authors such as Chinua Achebe, Ayi Kwei Armah, Ngugi wa Thiong'o and Kenjo Jumbam have celebrated the African woman, and even if some of their works engage with patriarchal ordering, it is obviously not with Western connotations. The overwhelming questions to answer would include: What gender interpretations? Which cultural contexts? From what angles and whose theoretical perspectives? This is worth serious research.

\section{Tracing the movements and itineraries}

The following figures attempt a graphic representation of the discussion. These representations do not mean full cycle of travel or permanence of discourse in any location. Circulation is continuous and unending, generating more discourses and multiple routes. 


Poststructuralimm/Decoustruction in the
US: Trausatlantic adaptatious and new
dep artures
Literary in plications/ theory and m ethod
Yale Critics. Paul de Man, I Hillis Miller,
Geoffrey Har man, Harold B loon
The collapse of Deconstruction and the
paving of the way to Cultural studies
minority discourses and new historicists
fom ulations
Postcolonial connections with Said,
Bhabha, Spivak

PoststructuralismDecou struction
in Europe: another location of
entry and departure
Philosophical tum: Deconstruction of
logocentricizn
Nietzsche
Derrida, Althusser, Lyotard
Bourdieu, Cix ous Kristeva
Foucault, Bourdieu, Barthes
Fovcault
Robert Young's poststructuralist and
postcolonial connections

\section{Western discour s: An erica}

Morement to the US<smiles>C1CCCC1</smiles>

\section{Morement to Afric a}
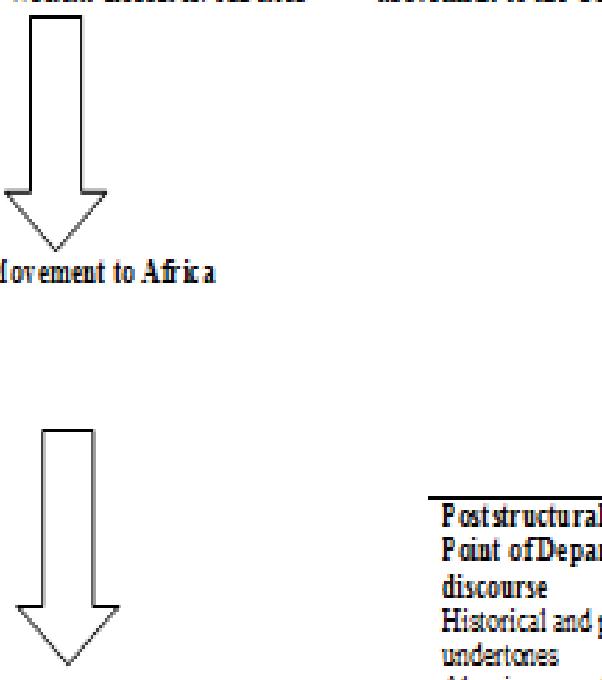

Acknowledged or unachnowledged accom modation in postcolonial studies

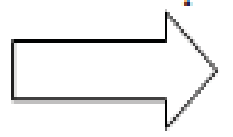

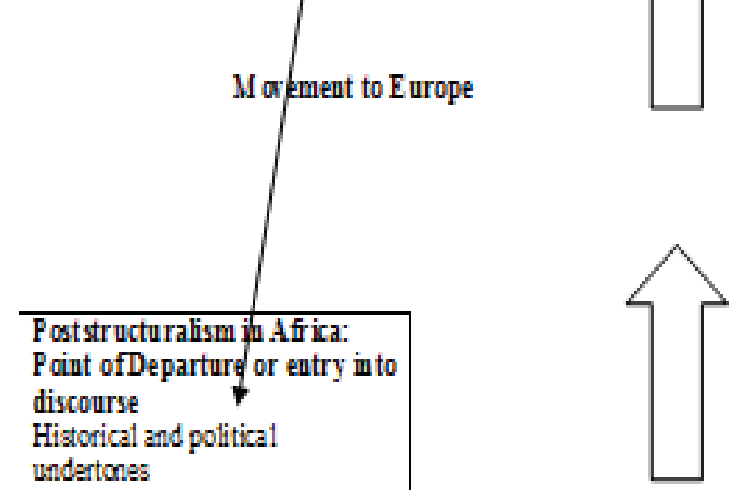

Algerian war of independence:

Derride, Cixass, Althusser,

Lyotard Bourdien Fanon,

Menmi

Postcolonial affiliations with

Cultural studies minority studies new historicizn as "posf"

poststructuralizm

Achebe, Ngugi, Irele, Olaniyan

Gikand, Mbenbe, Appiah,

Ogede

Figure 1 Poststructur alism and itsmor ements 
USA

- White feninist African Amerian fen inist and African diaspora fem inist -Social construction of African gender Eur ope
-White fem inists
-Black British Fen irists: advocacy
for multiple subjectivities
African diaspora fem inists:
genera ting and inspiring fem inist
morements in Africa hegen ony in a hyper heter ogenecus - Western feninist contex to - Contestations $\propto n$, race, gender, class -Site of difference: African America American brand of fem inism
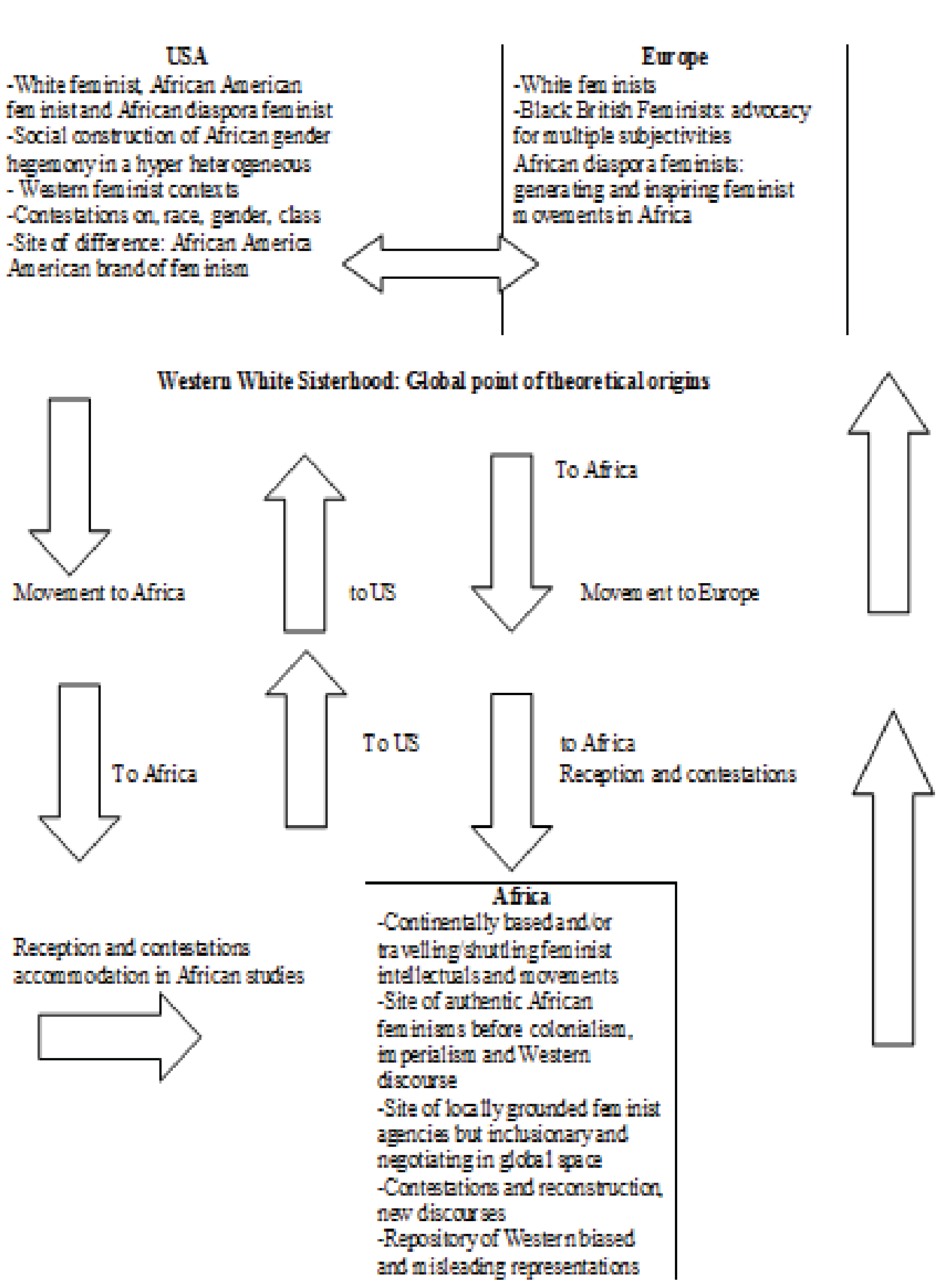

Figure 2 Feminist theory and its straddling borders

\section{Conclusion}

This essay has focussed on the question of travelling theory, underscoring its relevance in postcolonial criticism with regard to two related theoretical perspectives commonly associated with the West, namely poststructuralism and feminism. It contends that understanding the intricacies of travel theory contributes varieties of positions which are hardly 
ever homogeneous. Postcolonial criticism is a synergic space of myriad theoretical voices. Its strength, more than any other critical theory, is rooted in its endogenous ecumenism. African criticism as a subset of postcolonial discourses enjoys this privileged position. Appropriating African studies with poststructuralism to which it has contributed, neither erodes nor renders African aesthetics and criticisms fluid or fragile. The question of feminism in Africa as travel theory has contributed productively in reconstructing, re-imaging and narrating the African woman within global feminist engagements. This paper is a trajectory in the mainstream discourse of its subject. It cannot do justice to a debate as controversial as postcolonial affiliations with Western theoretical paradigms. It has assumed no finite position, because it certainly will generate or inspire other trajectories. It ends without ending the richness and diversity of opinions.

\section{Acknowledgments}

The research leading to this academic paper has received funding from the European Union Seventh Framework Programme [FP7 (2007 - 2013)] under Grant Agreement no PIIF - GA - 2011 - 298634 CAMLIT.

I would also like to express gratitude to the Bayreuth International Graduate School of African Studies (BIGSAS) University of Bayreuth for permitting me to explore its rich library and providing me research space. I am particularly indebted to Gilbert Ndi Shang's personal library of postcolonial and multicultural studies.

\section{References}

Andraş, Carmen. "The Poetics and Politics of Travel: an Overview" Philologica Jassyensia, An II, Nr. 2, 2006. 159 - 167.

Akin-Aina, Sinmi. "Beyond an Epistemology of Bread, Butter Culture and Power: Mapping the African Feminist Movement," Nokoko 2, 2011. 62 - 89 .

Appiah, Kwame Anthony. 'Is the Post - in Postmodernism the Post - in Postcolonial,' Critical Inquiry 17. 1991. 336 - 57.

Ashcroft, Bill. Postcolonial Transformation. London: Routledge, 2001.

Bal, Mieke. Travelling Concepts in the Humanities: A Rough Guide. London: Toronto University Press, 2002.

Chinweizu et al. Toward the Decolonization of African Literature. Washington: Howard University Press, 1983.

Clarke, Richard. "Travelling Philosophy" Conversations II: Western and Non-Western Philosophies. University of the West Indies, Cave Hill, Barbados, March 2, 2006.

Clifford, James. "Notes on Travel and Theory". Centre for Cultural Studies. culturalstudies.ucsc.edu/PUBS/Inscriptions/vol_5/Clifford.html

Clifford, James. Routes. Travel and Translations in the Late Twentieth Century. Harvard: Harvard University Press, 1997.

Gikandi, Simon. "Poststructuralism and Postcolonial Discourse," (2004) in Tejumola Olaniyan and Ato Quayson, eds. African Literature: An Anthology of Criticism and Theory. Oxford: Blackwell Publishing, 2007. $614-620$.

Huddart, David. Postcolonial Theory and Autobiography. New York: Routledge, 2008.

Lazarus, Neil. "The Fetish of "the West" in Postcolonial Theory," in Crystal Bartolovich and Neil Lazarus, eds. Marxism, Modernity, and Postcolonial Studies. Cambridge: Cambridge University Press, 2002. 43 - 64.

Leonard, Philip. Nationality Between Postructuralism and Postcolonial Theory: A New Cosmopolitanism. New York: Palgrave Macmillan, 2005.

Lützeler, Paul M. "From Postmodernism to Postcolonialism: On the Interrelation of the Discourses," TRANS: Internet-Zeitschrift für Kultuwissenchaften. No 11/2001. Accessed 08 April 2012. http://www.inst.at/trans/11Nr/luetzeler11.htm

Mama, Amina. Beyond the Masks: Race, Gender and Subjectivity. London: Routledge, 1995.

Mama, Amina. "What does it mean to do feminist research in African contexts," Feminist Review Conference Proceedings, 2011. 3 - 20.

Mazuri, Ali A. The Africans: A Triple Heritage. Boston: Little, Brown and Company, 1986.

Nnaemeka, Obioma N. "Bringing African Women into the Classroom," (1994) in Tejumola Olaniyan and Ato Quayson, eds. African Literature: An Anthology of Criticism and Theory. Oxford: Blackwell Publishing, 2007. 570 - 577.

Nnaemeka, Obioma N. "Nego Feminism: Theorizing, Practicing, and Pruning Africa's Way," in Signs, 29(2), 2004. 357 - 385.

Nnaemeka, Obioma. "If Female Circumcision Did Not Exist, Western Feminism Would Invent It," in Susan Perry and Celeste Schenck eds. Eye to Eye: Women Practicing Development Across Cultures. London: Zed Books, 2001.

Nnaemeka N. Obioma. "Bringing African Women into the Classroom: Rethinking Pedagogy and Epistemology," in Margaret Higgonet, ed. Border Work: Feminist Engagements with Comparative Literature. Ithaca: Cornell University Press, 1994. 301 - 318.

Ngugi, wa Thiong'o. Globalectics: Theory and the Politics of Knowing. New York: Columbia University Press, 2012.

Ngugi, wa Thiong'o. Moving the Centre: The Struggle for Cultural Freedoms. London: James Currey, 1993.

Nyamnjoh, Francis. "Potted Plants in Greenhouses: A Critical Reflection on the Resilience of Colonial Education in Africa" in Journal of Asian and African Studies. 2012.

Ogundipe-Leslie, Molara. "Stiwanism: Feminism in an African Context," (1994) in Tejumola Olaniyan and Ato Quayson, eds. African Literature: An Anthology of Criticism and Theory. Oxford: Blackwell Publishing, 2007. 542 - 550.

Ojaide, Tanure. "African Literary Aesthetics: Continuity and Change" in Journal of the African Literature Association. Vol. 6/2. 2012. 114 $-132$.

Ojaide, Tanure. Poetic Imagination in Black Africa: Essays on African Poetry. Carolina: Carolina Academic Press, 1996. 
Olaniyan, Tejumola. "Postmodernity, Postcoloniality, and African Studies," (2003) in Tejumola Olaniyan and Ato Quayson, eds. African Literature: An Anthology of Criticism and Theory. Oxford: Blackwell Publishing, 2007. 637 - 645.

Oyewumi, O. "Visualizing the Body: Western Theories and African Subjects," in African gender studies: a reader. New York: Palgrave, 2005. 3-21.

Oyewumi, O. African Women and Feminism: Reflecting on the Politics of Sisterhood. Trenton, NJ: Africa World Press, 2004.

Rich, Adrienne. Blood, Bread and Poetry: Selected Prose From 1979 - 1985. New York: Norton, 1994

Said, Edward. The World, the Text, the Critic. London: Faber \& Faber, 1984.

Salo, Elaine. "Talking about Feminism in Africa: Interview with Amina Mama" Agenda: Empowering Women for gender equity. Vol. 16/50. 2001. 58 - 63. http://www.wworld.org/programs/regions/africa/amina_mama.htm

Spivak, Gayatri Chakravorty: The Post-colonial Critic: Interviews, Strategies, Dialogues.

London and New York: Routledge, 1990.

Teke, Charles Ngiewih. "S. T. Coleridge and German Transcendental Philosophy: Influence or Confluence?", Academic Research International. Vol. 3/3. 2012. 313 - 321.

Teke, Charles Ngiewih. Towards a Poetics of Becoming: Samuel Taylor Coleridge's and John Keats's Aesthetics between Deconstruction and Idealism. Regensburg: University of Regensburg Publishing, 2006.

Tiffin, Helen. "Post-Colonialism, postmodernism and the Rehabilitation of PostColonial History," Journal of Commonwealth Literature, XXX, 2, 1993.

Young, Robert J. C. "Subjectivity and History: Derrida in Algeria," (2001) in Tejumola Olaniyan and Ato Quayson, eds. African Literature: An Anthology of Criticism and Theory. Oxford: Blackwell Publishing, 2007. $621-627$.

Young, Robert J. C. "Deconstruction and the Postcolonial", in Deconstructions: A User's Guide, ed. Nicholas Royle (Basingstoke: Palgrave, 2000) 187-210.

Zeleza, Paul Tiyambe. "The Troubled Encounter Between Postcolonialism and African History;" Journal of the Canadian Historical Associtaion. Vol. 17/2. 2006. 89 - 129.

Zima, Peter V. Deconstruction and Critical Theory. Trans. Rainer Emig. London: Continuum, 2002. 